\title{
Towards a sonic ecology of urban life: ethnography of sound perception in Cairo
}

\author{
Vincent Battesti iD $^{\mathrm{a}}$ and Nicolas Puig (D) ${ }^{\mathrm{b}}$ \\ aUMR 7206 Éco-anthropologie, CNRS, Muséum national d'histoire naturelle, Université de Paris; Musée de \\ I'Homme, Paris, France; 'bniversité de Paris, URMIS, IRD, CNRS, Paris, France
}

\begin{abstract}
This study on sound perception in Cairo uses a methodological procedure described in a previous issue of this journal [11(3)]. The procedure involves equipping inhabitants of Cairo, the Egyptian capital, with binaural microphones that record the surrounding urban sounds during one of their daily journeys (without the researcher). Participants later describe and comment on the sounds while listening to the recording. Analysis of this material allowed us first to establish an organized lexicon in categories. We identified a structured "natural language of sounds". The data obtained reveal covert categories that describe three key domains of urban life: the active city, the city in movement, and the relational city. A principal finding is that sound perception systematically relates sounds to their origin, i.e. both the source and its social situation. This socialization of sound led us to the notion of "sound constructs" as products of an immediate socialization of the perception of sound. Experiment clarifies how perception operates in Cairo, notably through territory differentiation using sonic saliences and soundmarks. Finally, we propose a "sonic ecology" of the city: how residents collectively experience the sound dimensions of their urban territory, navigate between very different territories, recognize them and respond to them.
\end{abstract}

\section{KEYWORDS}

Cairo; urban; ambiance; acoustic; sonic; sensory ethnography; binaural

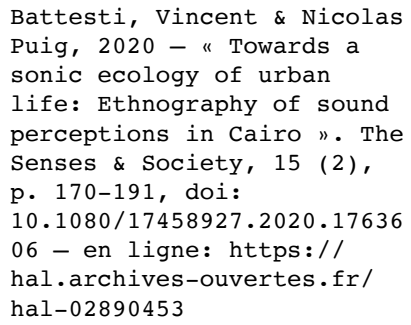

\section{Introduction}

The work and results presented in this text expand on a previous article, of which it forms a second part. In the first article, we described a procedure and method for investigating sound perceptions, which we called "Mics in the Ears" (Battesti and Puig 2016; Battesti 2017). In short, the procedure consists in equipping the residents of a place, here the Egyptian capital Cairo, with binaural microphones that record sound during a walk along a familiar route. Starting from the observation that the ordinary sound domain elicits little reflections or verbalization (Battesti 2013), except when the sound is considered a nuisance, this method set out to collect from participants, volunteers chosen from among Cairo's residents, descriptions of and comments on their urban sound environment. It is a technique designed to serve an anthropological investigation (far from any 
technical fetishization, Battesti forthcoming 2020) that aims to access the intimate sphere of everyday Cairo life; the overall procedure is grounded in long and essential ethnographic work conducted in Cairo (Battesti and Puig 2011).

How do we account for the relatively weak verbalization among residents regarding their everyday sound universe? One explanation, a minima, is that most of our sensory mechanisms operate unconsciously, which no doubt helps reduce excess cognitive loading (it would be impossible to consciously process all of the stimuli that our bodies encounter at once). Subsequently, the sensory experience remains infraverbal, but can be brought to awareness by this procedure.

Our aim is to update the "natural language of sounds," by which we mean ordinary language used in everyday life in Cairo to evoke one's acoustic experiences (Battesti and Puig 2016, 306). The methodological procedure first enabled us to collect sound recordings in situ, as close as possible and specific to each resident's everyday urban experience (equipped with binaural microphones, the way a person moves, maneuvers his or her body in the urban space, is registered in the audio recordings). It then provided access to this natural language and to participants' reflections when listening to the recording of their own walk, as well as to their comments, which sometimes take the form of a sonic semantics of social life (Battesti and Puig 2016; Battesti 2017).

The method was intended to be, and remains, very experimental. We focused on the intensive rather than the extensive: ten in-depth soundwalks and nine Egyptian participants (one participant did two walks), which is indeed very small, considering the city's population and size, but already provides a very good idea of residents' relation to the sound dimension of the city. We tried to bring certain differences into play: different neighborhoods, and, among participants, different generations, different social and economic backgrounds, and different genders (Figure 1).

The recording campaigns were conducted between 2011 and 2013 in different neighborhoods of Cairo: Wast al-Balad (downtown), Duwiqa, Darb al-Ahmar, Bashtil, Garden City, Ghamra (see location map in supplementary material). For more detail on the methodological aspect, we refer you to our previous publications (Battesti and Puig 2016; Battesti 2017).

\begin{tabular}{|c|c|c|c|c|c|c|c|c|}
\hline Participants & Date & District's route & Day/night & Age & Social Class & Gender & Education & Cairo district \\
\hline Hassan \#1 & 2011-10-25 & Darb al-Ahmar & day & ++ & + & $\delta$ & ++ & Darb al-Ahmar \\
\hline Mona & $2011-10-26$ & Bashtil & day & $+1+$ & + & 운 & + & Bashtil \\
\hline Leyla & $2011-10-27$ & Darb al-Ahmar & day & $+H$ & + & 우 & + & Darb al-Ahmar \\
\hline Shady & $2012-09-26$ & Wast al-Balad & night & + & + & $\delta$ & + & Darb al-Ahmar \\
\hline Salma & $2012-09-26$ & Wast al-Balad & night & + & ++ & $q$ & + & Manshiyat Nasr \\
\hline Samir & $2012-09-28$ & Bashtil & day & ++ & + & 3 & +++ & Bashtil \\
\hline Hassan \#2 & $2012-09-28$ & Duwiqa & night & $+1+$ & + & $\delta$ & ++ & Duwiqa \\
\hline Evelyn & 2013-05-29 & Wast al-Balad & day & ++++ & +++ & 우 & +++ & Wast al-Balad \\
\hline Maurice & 2013-05-30 & Garden City & day & +++ & ++ & $\delta$ & +++ & Garden City \\
\hline Mohammed & $2013-05-30$ & Ghamra & night & + & + & $\delta$ & ++ & Ghamra \\
\hline
\end{tabular}

Figure 1. Table of participants. 
In part 1 of this article, we present the data and analyze the results obtained with this procedure. In part 2, drawing on the empirical elements described, we propose an analysis/discussion focusing on the categorizations and domains of activity in the city. In part 3, we introduce a reflection on the concept of sonic ecology. The notion of "sonic ecology" allows us to integrate a specifically anthropological dimension, the emic perspective, and the variety of sound perceptions and productions that constitute and structure a given environment. Our approach aims to be more comprehensive - by integrating etic and emic approaches ${ }^{1}$ - than acoustic-ecology-based analyses (bioacoustics, Krause 2012) or studies focusing on ambiental properties. We are not seeking to produce an objective description of urban sound in Cairo but rather to understand, through sensory ethnography, the worlds that Cairo's residents inhabit, worlds that are partial of their own making (Photograph 1). We seek to go beyond ambiance-based approaches that have concentrated, from an etic perspective, on sound sociabilities, communication in markets, or the interplay of sounds in the passageways of large buildings (Augoyard 2003), all interesting and sometimes pioneering studies, but ones that have not considered first the emic point of view, the experience of residents, who are not only receivers but also always emitters of sound.

Finally, the goal of this article is not to undertake exhaustive analyses of all the data obtained from the experimental ethnographic method "Mics in the Ears" but, rather, to explore its possibilities. It is in this spirit that we are submitting, as supplementary material, all of the soundwalks and audio interviews, their transcriptions, and lexicons, to be re-used within the scientific community as a whole (https://zenodo.org/commu nities/sonic-ecology-cairo).

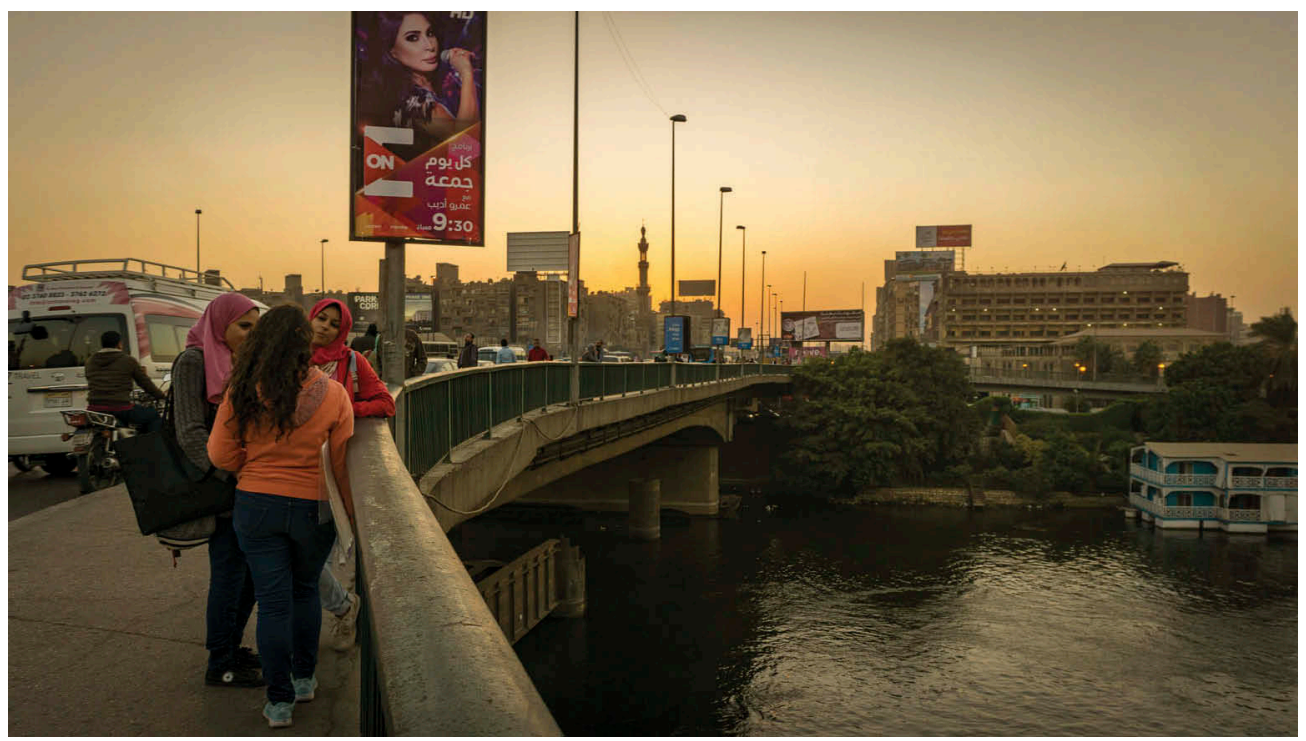

Photograph 1. Young women chatting on the crowded 15 May bridge over the Nile, Cairo, Egypt, end of day, November 27, 2016, by Vincent Battesti. 


\section{Part 1. The lexicon of the natural language of sounds}

The ethnographic procedure "Mics in the Ears," developed to study the modalities of relations to the sound dimension of the city, produced several types of data: soundwalks (audio recordings made by residents with binaural microphones); audio recordings of descriptions made by the same individuals during playback of their soundwalk and corresponding transcriptions (in Arabic and French); audio recordings of the same individuals' comments on their experience of the sound dimension and corresponding transcriptions (in Arabic and French). We thus obtained accounts of the soundwalks in which participants describe and comment on the sounds heard while relistening to their recorded walk. This material comprises many pages of transcriptions in Arabic from which we have extracted elements related to the verbalization of their sound experience. We identified 600 entries divided into five classes: "nouns," "sound sources," "qualificatives/descriptives," "actions/ verbs," and "localizations of the sound event." Together they form the lexicon of what can be called the "natural language of sounds" in Cairo, as described below.

(a) - Nouns of the sound register

In general, before entering into the details of the lexicon, we note the limited diversity of vocabulary that emerged from our procedure: around 40 terms serve to directly designate a type of sound (see Lexicon: NOUNS). An initial observation is that Cairo society has not sought to distinguish between "sound" and "voice," using the term "șawt" (صوت) as in Classical Arabic for the two acceptations (which are distinct terms in French or English, for example).

We have retained in this register expressions like mazikā (music), ambient sound (in English), dagig (noise), daw dāa' (din) or dawša (noise, racket), and the emblematic gaw (atmosphere, which encompasses sounds as well as other sensory domains, Battesti 2013).

One part of this lexicon refers to the ambiance of a place (thus often to spatialization): gaw samāeī (auditory atmosphere), manax (climate), manzar el-عaìd (festive decor), mašhad (sound scene). Another part refers explicitly to sound effects - dabdabāt (vibration), wašš (interference noise), efektēt (effects), ekko (echo), riferb (reverberation), beat (rhythm) - and appraisals of sound intensity - hudu' (calm), sukūt (silence), rāha (rest), ḍawḍ̄' (din). Finally, we note nouns designating sound emissions: the omnipresent klakson (horn, siren), the safar (whistling), the human voice (sawt), etc., and a set of onomatopoeias designating sound emissions that do not correspond to nouns in the linguistic register - pip! pip! pip! pip! pip! (concert of horns), tak! (blue lamp that kills mosquitos), tik-tik, tik-tik, tik-tik! (iron of the makwagi) - rather too small in number for the requested exercise.

This lexical scarcity confirms one of our previous observations (Battesti and Puig 2016): descriptions and comments responding to the question "what do you hear?" rarely refer to the sound itself (the types of sounds), but more often to the content of the messages transmitted (verbal communication, for example) or to the sources of the sound (for example, "this is the sound of a car").

(b) - Sources

In semiological terms, it seems that every urban sound that merits description for our participants is a sign, and thus potentially has a signifier and signified. None of the participants described the 
sonic qualities of the sound in itself, that is to say the signifier; all, rather, concentrated on the referent (the element in reality to which the sign refers, the source) and/or the signified: for example, during the listening session, rather than describing the music discerned, the participant associated it with the sound coming from the microbus (its source: the referent) or with an event, a wedding party (the social signified). This social signified is sometimes a self-explanatory event such as a wedding (people getting married), or whose intention must be explained (this man must be in a hurry). In the following passages, the participants do not evoke the sound itself (the signifier), but instead interpret the situation (signified):

[12:39] - A woman is passing by with her children in the hara. (...)

[13:48] - Children are running. [Leyla]

[04:40] - (...) This is a guy in a big hurry honking his horn. [Salma]

It is an ordinary listening, to the point that the vocabulary employed, just as ordinary, does not make use of an expert register or discourse. The descriptions that we obtained include very few new or specialized words. On the other hand, the lexicon extracted from this experimental procedure is rich with terms referring to the sources of sound emissions identified.

The sources of sound are abundantly noted by the participants (see Lexicon: SOURCES): close to 260 entries, the longest list of terms in our lexicon. Participants systematically associate the sources with social situations rather than considering them autonomously, as "sound objects," in Pierre Schaeffer's sense (1966). For Schaeffer, the definition of the sound object begins with a revelation, the acousmatic revelation triggered by hearing sounds whose source remains invisible: in isolating the sound from its context of origin, the reduced listening allows the listener to concentrate on the sound object, independently of its causes or meaning (Chion 1983).

Our sensory ethnographic study on ordinary listening revealed a contrario what we have termed "sound constructs." Sounds are not considered autonomously here: regardless of their acoustic characteristics, they are related both to their source and/or to a social situation (referent and signified). "Sound constructs" are thus products of an immediate socialization of the perception of sound related to an acquired competence, an ability to decipher the sound dimension of urban/social life and act accordingly. These sound constructs, in participants' descriptions of what they hear, are compiled under the heading "SOURCES": "this is the sound of ..." a café, elderly people, the fruit vendor, the butcher, the staircase, birds in someone's house, shoemakers, someone arguing on the telephone, a quarrel, microbus drivers, the Holy Quran, people greeting each other, and so on.

Despite the length of the list of sound emitters identified by the participants, no overt (explicit) or covert (implicit, see Berlin, Breedlove, and Raven 1968) emic categorizations emerged. We can still, however, propose criteria for an etic categorization, in order to organize this vast set of data and better understand its content (the purpose in fine of any categorization). One possibility would be to draw distinctions based on criteria of intentionality. On the one hand, this would include the sound productions noted that indicate an intention of communication (signs, in semiology) or participation in an ambiance, through the voice, the body, instruments (for example, horns, cart bells or whistles, calls to prayer, turning on the radio, etc.). On the other hand, it would include unintentional sound productions wherein the sound produced is not the first purpose of the action (even if it may guide it, serve as a support, or foster communication), for example, the 
sound of artisanal activities, forms of traffic, and so on (the butcher pounding the meat, the upholsterers tapping on chairs, public transport, a rattling Vespa, a plastic bag, etc.). These can constitute indices in semiology (in this paper, the index differs from the sign in that its first function is not that of signifying something: it is signifying, but unconventional, involuntary, and variously interpretable).

Other binary etic categorizations are possible: mechanical versus other sources, or the vocal apparatus (speech, laughter, coughing, sobbing) versus other sources, for example. Bernie Krause's now canonical etic classification (2002, 2012) distinguishing between anthro[po]phony, biophony, and geophony would provide a rather poor breakdown for Cairo: nothing is noted in the geophonic register, only three bird entries (including domestic birds) and one each for a dog, a cat, a donkey, and a horse make up the biophonic register, and all the rest would be classified in the anthropophonic register. Clearly, we find ourselves here in an extremely "anthropized" sound universe, or at least one in which the sound sources identified by participants are essentially (at 97\%) of anthropogenic origin. In the comparative perspective dear to anthropology, it would be interesting to correlate this breakdown with that of other cities in the world.

\section{(c) - Qualificatives/descriptives}

It first appeared to us that the sound qualities attributed to sounds heard by the participants (see Lexicon: QUALITIES) could be divided - again using our etic categories into two broad classes, acoustic descriptors and more explicitly moral descriptors. Upon reflection, this breakdown does not seem very pertinent to us insofar as the boundary between acoustic and moral descriptors is porous. An acoustic appreciation often proves to have a normative dimension: for example, "Egyptians are loud," "unpleasant sounds," "noisy sounds," "melodic ambiance," etc. Two other slightly different classes can be proposed: acoustic versus hedonic descriptors (without entirely eliminating the same ambiguity). Hedonic descriptions refer to judgments such as "I like/l don't like," "awful background noise," "nice sound," "very jarring voice," "unpleasant sound," etc., while acoustic descriptors are most often related to volume ("much louder sound," "powerful sound," "sound like a missile," "gentle" "calm") or to the clarity of sounds heard ("clear/ distinct sound," "you hear every detail of what they are saying," "confused," etc.).

\section{(d) - Actions/verbs}

Sound reception and production are de facto intimately linked. A large majority of verbs used in the natural language of Cairo (see Lexicon: VERBS) refer to the production of sounds by others ("the shoemakers were hammering," "they're loudly playing (together)," "microbuses screaming at each other," "he's playing music"), whereas a single verb samaع (to hear) is used to describe almost all of the sound receptions: "I don't hear well," "I hear clearly," etc.

Among all of these natural language verbs used in the sound domain, a vast majority (86\%) are associated with human agents ("they're yelling," "footsteps on the ground," "he is advertising (his eggplants)," "people are talking," "they're calling people (scalpers)," "the caretaker's children are crying") and include a wide variety of action verbs (to hum, to hit, to talk, to play, to call, to scrape, to scream, to yelp, etc.). The remaining smaller portion most often refers to human action sounds attributed to an object using rhetoric or personification: for example, 
"microbuses screaming at each other," "cars honking," "bottles banging together." Others eliminate the human emitter ("the call [to prayer] was done"). The rare objects noted for emitting the sound themselves are "the Vespa that is rattling," "the telephone is ringing," "(the sound of the TV) is coming out of (the house)," "the sound/song of the birds is getting louder."

Among the action verbs dedicated to sound production, half are related to the human voice: "she is bawling," "the bawab [concierge] is greeting me," "people are yelling," "he's whistling," "he is raising his voice," "people are calling each other," "I was humming," "the caretaker's children are crying," etc. This pronounced vocality of space would likely be considerably reduced if we had not chosen to focus on neighborhoods in the city's limits; the ambiance is something else altogether in the new middle- and upper-class neighborhoods of the gated community type in the greater suburban Cairo area (Katameya Heights, for example), where all travel takes place by car and urban life is generally very different (see Battesti and Puig 2011).

(e) - Localization of the sound event

Localization first involves participants spatially locating the sounds perceived in relation to their own position during the walk, which entails a self-referencing of sounds: "he began to come closer" (implying "closer to me"); "far away" (from me); "to the right of me"; "sound coming from the center" (in relation to me); "the sound of a cart coming from afar" (far from me); the "sound of a wedding moving away" (I'm moving away from the sound), etc. (see Lexicon: LOCALIZATION).

[02:04] - [During the playback] we are coming across people and their talking. [Salma]

Added to this spatial self-localization are a few rare localizations in time: "not long ago"; "now." Even more rare are references to the duration of sounds: "the sound of children playing continues." Temporal annotations are far less present in the lexicon than references to the localization of sounds in space, participants seeking first to situate their position and the position of sounds in space. This effort reveals their immersion in the city's flows. Participants are surrounded by motorbikes, cars, and people, and they are also on the move: they move away, pass through and/or approach sound environments. The descriptions of the soundwalks reflect this immersive experience. The sound space has a depth that the localizations convey, the binaural microphones being particularly effective in reproducing the spatial perception of sounds.

Participants describe the spatialization of sounds first by using place names, mainly with reference to generic spaces and, to a lesser extent, toponyms. The places evoked include traffic spaces ("alleyways," "level crossings," "square," "small square," "large exterior avenue," "exterior street," "hara"), businesses ("meatloaf vendor," "souk," "košarī restaurant," "grocery stores," "eatery," "café"), and domestic spaces ("house," "staircase," "lobby").

The lexicon for describing different territories of the city (neighborhoods) is relatively extensive. Social characteristics are attributed to them: "first-class bourgeois neighborhood," "working-class neighborhood," "affluent neighborhood," "banking district," etc. This qualification is reinforced by the toponymy employed that primarily specifies the names of neighborhoods, streets, and popular cafés (Café riche, café Abdel Halim, café Umm Kulthum).

What are we to make of the temporal status of these recorded walks? How do participants grasp the temporal dimension of their route and of the circulation of sounds, beyond the words employed? By comparing the descriptions and comments with the audio recordings of the walks, we can distinguish three modalities for 
rendering the temporality of sounds, all of which are linked to movement, to the conjunction of the temporal and the spatial.

The first modality involves vigilance or alertness: the participant immersed in the traffic identifies the sounds of vehicles around him, which he has learned to recognize for his own protection, as in the following example: "a motorbike approaching, arriving, passed." Vigilance also involves calls from acquaintances hailing participants in the street, to which the latter must respond. The second temporal modality of sound occurs when a noise gradually becomes louder over the course of the walk, to finally be present and thus mentioned in the description (for example, an approaching music, which becomes louder and louder, before receding once the source is passed by). The last modality is the sound event which occurs during the walk (for example, the call to prayer).

In general, spatial and temporal localization is not easy for participants. During the playback of their walk, hesitations, or errors emerge that are eventually corrected. Several participants had a tendency to shorten their walks in their oral descriptions when listening to them on headphones. They had the impression of being a lot closer to home than they often were in reality, as though time were passing more slowly during the listening than during the walk itself. In our experiment, these distortions always entailed a shortening and not a lengthening of the walk.

\section{Part 2. Sound constructs and covert (implicit) categorizations: perceptive modes, urban activities}

(a) - The sound construct: a way of perceiving

Our study results confirmed what we suspected, that "our Cairo informants have more pointed to sound as vehicle than described the sonorities: maybe the average Cairo citizen is much more a semiologist than an acoustician" (Battesti 2017, 150). This indicates that acoustic and social properties are inseparable (Photograph 2). To go beyond the

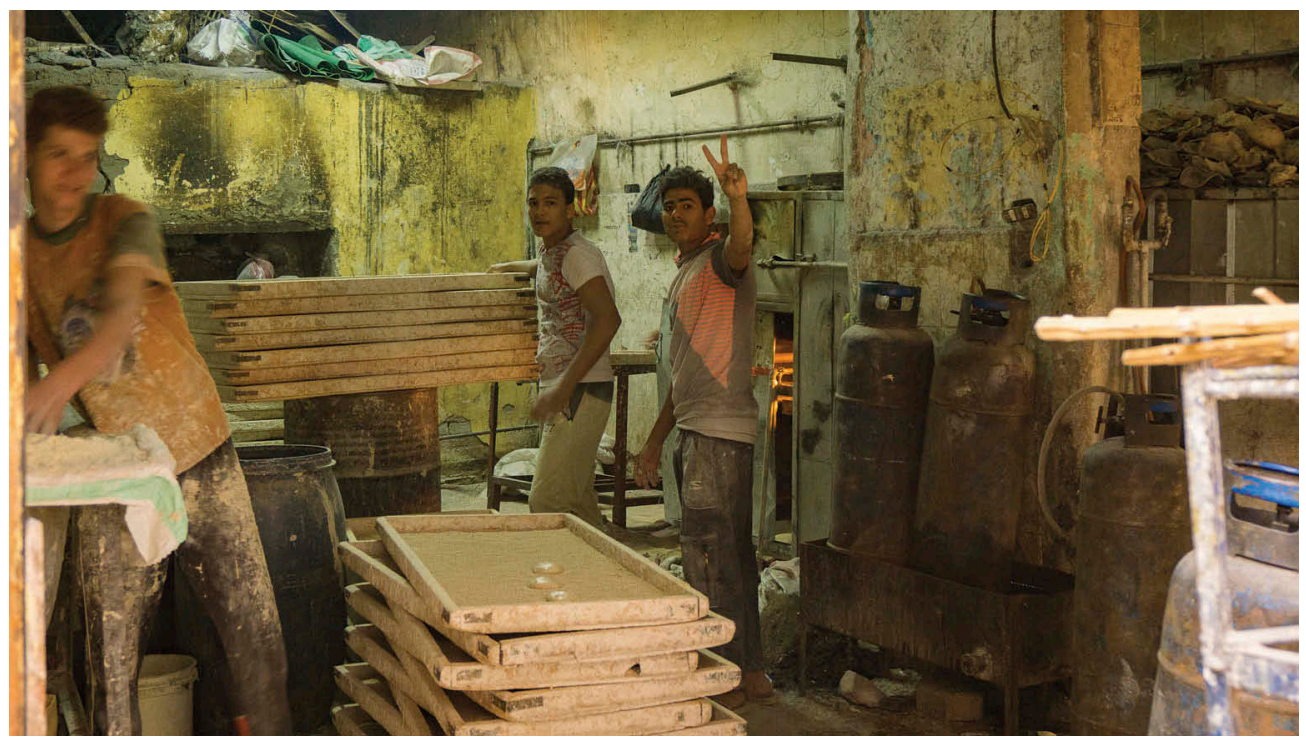

Photograph 2. Young baker's boys at work in a bakery open on a bustling street in the old working-class neighborhood of Bab al-Sha'iriya, Cairo, Egypt, mid-afternoon, November 28, 2016, by Vincent Battesti. 
reception or perception of sound by including the issue of its production, it seems more appropriate to us to employ the term "sonic ecology" to refer to what we previously termed "acoustic ecology" (Battesti and Puig 2016, 305-306), as "the system formed by the different ways of inhabiting a sound space and producing one's own sound space within a given environment."

Sound perception, as understood here, is not constructed through reduced listening but, rather, through the association of sounds with their source, which is always identified and socially situated. Instead of focusing on sound objects (Schaeffer 1966), we foreground the notion of sound constructs to emphasize people's ability to socialize sounds. This socially acquired acoustic competence stems from a familiarity that enables residents to distinguish sound events in this continuum as a result of saliencies (the sound of the mosque, a car horn, people talking, a vehicle passing, etc.). We could refer in our context to "sonic saliences." These sonic saliences are comprised of a combination of acoustic properties (rhythm, sound intensity, melody, harmonies, attacks, or structure) and the indexicality of the sound construct (sounds take on meaning through their social situation of production/existence). For example, the very familiar tinkling of a metal spoon on glass - "the guy stirring tea" [Mona] -, or the well-known sound of domino games or tawla (backgammon), possess unique acoustic attributes coupled with social attributes that recall the signature sounds of the café world, a preeminent institution of Cairo social life.

In this way, to situate themselves in a sound continuum, the city's residents are able to apprehend these "sonic saliences" to orient themselves along their urban trajectory and ascribe meaning to what they hear. These sonic saliences are sounds that are singled out (whether recognized or not), the fruit of an acoustic knowledge of the city, born of the urban experience. One of us has investigated the case of the blind in Cairo (Battesti in 2016-2017: unpublished) using the "aural postcards" procedure (see below), which clearly revealed the indexicality of sounds to be directly related to personal experience or knowledge of the city's territories, of the urban ambiances of Cairo that these individuals had accumulated ... which does not exclude, for all residents, factual errors regarding the interpretation of indices and even signs (see, for example, hesitations in the localizations of Salma, Leyla, Shady, or Evelyn during their walks).

When sonic saliences enable residents to situate themselves in time and space, they take the form of reference points and can be refined into landmarks and soundmarks, each of which possesses singular acoustic and social signatures. If we define a landmark ${ }^{2}$ as an index, unique but shared by all, that marks out a precise space or time - in the manner of Schafer's foghorns in Vancouver (1978) -, these are either very few in number or not identified in this procedure. The call to prayer that resonates across the city nonetheless makes it possible to situate oneself in time. On the other hand, participants are a lot more forthcoming when noting the soundmarks of different types of spaces. A soundmark allows members of a community (at different scales) to identify a type of time or space and sometimes to infer a specific time or space. This could be a soundmark shared by the neighborhood or a more intimate one (elevators, voices of a doorman, and his children, among residents of the same building). For Evelyn, the sound of "upholsterers tapping on chairs" (description, Evelyn 04:40) is the irrefutable index of her localization close to home. On a larger community scale, when residents are listening to busy shopping streets of popular neighborhoods, the relevant soundmarks often noticed are the šibšib (flip-flops) 
dragged through the dust, the familiar or offhand manners people address each other, or the usual greetings used among acquaintances. These signal territories of acquaintanceship that are distinct from the anonymous territories of downtown (Battesti 2017, 137).

Secondly, the results indicate an absence of strongly verbalized emic categorizations. Categorization is however the activity that makes it possible to apprehend the world in order to understand and interact with it. Seen through the lens of a genuine theory of categorization (Rosch 1973), certain sounds or sound events would have to acquire a prototypical character, implying that some of them could be prototypes, that is, "central tendencies of categories" (ibid.) or "cognitive reference points for perceptual consciousness," as Candau and Wathelet describe it $(2011,39)$. The latter conclude that this theory of categorization cannot be applied to the perception of odors. In light of our own experiment's results, we are likewise compelled to conclude that categorization is not the primary tool through which residents of Cairo apprehend their sound universe. This can perhaps be explained by the fact that this sound dimension is not an object of discourse among residents, that it is not discussed; an essential dimension of city life, residents only rely on it in the moment/situation and interpret it, on the basis of saliencies, as a series of social constructs, combining acoustic properties and social indexations. Sonic saliences, it seems, are the cognitive tools replacing the absent categorizations.

Meta-analysis of the verbalized descriptions of sound does however reveal a division of the city into key domains of activity, a division that attests to the existence of implicit or covert categories.

(b) - The sounds of the city according to domain

"Everything is interlinked: the sounds of tools [așwāt al-alatā], the sounds of machines [așwāt makan], the sounds [așwāt] of cars, the sounds of people walking [așwāt al-nēs māšiya] in the street, the sounds [așwāt] of the mosques, the sounds [așāt] of people walking on the ground and then ... people greeting one another [nēs bethayī bacaḍiha], people comforting one another, it's lively [al-wanas], it's lively, it's got soul." [Hassan \#1]

Beyond the lexicographic analysis, the data collected allow us to identify semantic content. From our point of view, three main domains of urban life emerge from the participants' descriptions: (1) the active city, (2) the city in movement, and (3) the relational city. These three domains partially overlap with those isolated by the urban anthropologist Ulf Hannerz (1980) to characterize the organization of the modern Western city: (1) household and kinship, (2) provisioning, (3) recreation, (4) neighboring, and (5) traffic (ibid.: 102). They differ primarily in that our procedure focused on isolating the sound characteristics of public urban spaces, leaving aside the whole sphere of private and domestic space. It is this public city that participants describe in their discourse. One has to keep in mind that there is, on the one hand, always an overlapping of domains that makes it difficult for residents to focus on or distinguish between the activity, the movement, and the relational, and, on the other, a domain of ordinary perception (and ordinary life) - characterized by the epoche of the natural attitude (Schütz 1962, 229) - which entails the suspension of all doubt regarding the existence of the external world and its objects. This natural attitude involves the conviction that the world and its objects are as they appear to us (Puig 2005, 196). It is accompanied by 
what we might call a "natural listening," wherein the sound is always treated as a "vehicle" of something to which it is linked (Battesti 2013, 77).

\section{The active city (artisans, businesses, mosques)}

The first domain that emerges from the participants' descriptions is that of a city marked by activity: these include businesses, artisans, cafés and restaurants, mosques, and so on. The activity varies from one territory of the city to another, but a lot of neighborhoods are marked by a significant presence of local businesses and markets, but also of artisans who leave their own mark on the sound environment. This is well noted by participants: licorice juice vendor, fruit vendor, butcher, fashion boutique, store selling chicken, košarī restaurant, a café playing music, boilermakers, blacksmith punching iron, souk, etc. Moreover, without being systematic, participants often noted the very real presence of numerous cafés and mosques.

In terms of activity, the artisanal presence is detected through the omnipresence of hitting sounds (percussion) that form evident saliencies: the butcher pounding the meat, the upholsterers tapping on chairs, the shoemakers hammering, etc.

\section{The city in movement (mobility)}

Amin (2000) recounts a striking anecdote about growing turmoil in the city: a blind man confined to his home is pleased to hear traffic sounds increasing over the decades, interpreting this as a sign of the country's development and the city's growing wealth, when in fact the opposite was true for Cairo's residents, who were becoming poorer over the years. As a resident of the working-class neighborhood of Dūwīqa summed it up in early 2000, "it's poverty that keeps the city moving" (Puig 2003, 148). ${ }^{3}$ Without reducing it to the issue of poverty, participants note the intensity of movement in the city and the issue of traffic and congestion (zahma).

The integration of residents in the city's flows explains the prevalence of perceptions linked to traffic. The participants are themselves mobile (following their route) and caught in the traffic. This position creates a state of alert, evoked above, that has an influence on their perception of sounds. They often move their heads to direct their ears to the sound of a vehicle (a car, Vespa, motorbike, scooter, bicycle, etc.) or an acquaintance calling out to them. They turn around, for example, to identify the source of a sound so they can move out of the way or respond to a greeting. Movement and perception are thus closely linked, ${ }^{4}$ a fortiori in these situations of alert. The descriptions of the walks contain numerous references to situations of encounters with vehicles:

[01:40] - (...) The sound [șawt] of a car coming and a motorbike [makana], rickshaw [tūktūk], car ['arabiyya], the sound of a café [sawt qahwa] and the television in the café ...

[03:45] - The sound [șawt] of a car coming in the distance, so I watch out for it, so I say to him [to his son] "Come!"

[07:00] - (...) People passing and complaining to each other [betešteki li-bacẹ]. A sound [șawt] like [that of] a motorbike [makana] coming from afar, while I'm entering the food [supermarket]. The motorbike [motosikl] is coming ... the motorbike is coming. Another motorbike [motosikl] is coming ... another car is coming, like ... like a tüktūk. [Mona] 
They also bear witness to minimal forms of communication between vehicles:

"He's honking, because he can't pass, another car at the stop honking so he can pass. And, there, it's passed." [Mona]

In the narrow streets of the medieval city, traffic circulates amidst human activities and less often involves cars than two-wheeled vehicles and carts. At the beginning of her walk, Leyla notes the passing of three Vespas:

“(...) I'm walking in the street, a Vespa is passing next to me ... It's normal, I'm walking in the street and people are walking, it's normal, there's no problem ... Vendors are talking in the street. A second Vespa is passing. Women are walking and buying things, vendors are talking. People are walking while laughing. Again a Vespa passing by." [Leyla]

Added to the sounds of motors and vehicles of every sort is the sound of footsteps in the street. In fact, the traction of feet on the ground is often noted by participants. The sound of people dragging their feet on the ground was an acoustic motif regularly identified as being emblematic of many residents' way of walking in these neighborhoods (Battesti and Puig 2016, 311-312). During his walk, Mohammed emphasizes the "movement of a lot of feet," "people's feet," "feet that stood out a lot" (while listening to the sound recording). Shady, for his part, emphasizes "the sound of feet," and Mona, "the sound of slippers." The sounds produced by people walking are very often noticed and associated with working-class neighborhoods, where tired workers lack the strength to lift their feet (see Mohammed's description at 04:31 and Battesti and Puig 2016, 311-312). The same participant pointed out that the "dragging of feet" distinguished the working-class neighborhoods (šacabiyya) from the affluent neighborhoods (raqiyya).

[07:00] - A [woman] is passing and arguing. The sound [șawt] of people walking and slippers [šibšib] dragging on the ground, and of noise [dawša]. [Mona]

\section{The relational city (interaction, relational density, sociability, social life)}

The last domain that emerged from participants' descriptions is that of a city marked by the intensity of interactions and by relational density. During their walks, participants recorded snippets of conversation, greetings, altercations, discussions, cries, or the voices of children playing or crying. These are sometimes known voices, neighborhood regulars whose voices they recognize, or, in larger neighborhoods, those of unknown residents but with whom they share ways of speaking and expressions, or finally, voices expressing a shared Egyptian/ Cairo dialect: these different levels of acquaintanceship contribute to instilling a climate of reassuring familiarity in which a natural attitude prevails (Battesti and Puig 2011; Puig 2005). Often participants repeat the words heard over the course of their route, when asked to say what they hear (see, for example, Mohammed's description).

[09:00] - He is saying to him "give me some money." The sound/voice [sawt] of people passing. A woman who's saying to her, she's speaking to her daughter: "you have to stay with your grandmother." [Mona]

During the playback of the recordings, it appears evident that residents navigate an urban conversation, interwoven with thousands of discussions and words exchanged in the public space. The city's conversation plays a reassuring role by providing a "sound coating" or protective envelope for some people (Battesti and Puig 2016, 316). 
"[The walker] finds the sounds/voices [aswat] of people around him comforting. He experiences warmth, feels safe in spite of the yelling [zacaiqq] and the racket [dawša] ... but at the same time, he feels very, very safe, he is able to interact with someone he doesn't know in the street. He's speaking directly with him, he is saying to him, questioning him about something, he is asking for help or offering to help him. That, that is society!" [Hassan \#1]

The vocality of the street constitutes a voice act that is inscribed in a collective construction (Féraud 2010). For the same participant, these street conversations, this "outpouring," is very important and plays a central social role in the regulation of behaviors:

\begin{abstract}
"The café and the voice [șawt] of the café owner [qahwagi] and people are talking, expressing themselves freely with passion [taläqa] and have no secrets. They have no restraint, they are expressing themselves, they are speaking loudly [sawt $\varepsilon \bar{a} l i]$, they are saying what's on their mind ... No one judges them, they speak as they wish and say all the things that bother them. To their friends and even to people walking down the street, they're sharing their concerns about a specific subject, this outpouring is very important, I could not walk in the street like this all alone ... everything is silent [sukūt], and I'm talking about a problem I have, I'm crying and becoming crazy in fact." [Hassan \#1]
\end{abstract}

\title{
Part 3. Sonic ecology, recognizing, and differentiating spaces and territories
}

(a) - Comprehensive listening

The results of the procedure demonstrate that the process of describing sounds involves a "socialization of sound" (Battesti and Puig 2016, 308). This is what led us to develop the notion of "sound constructs." Inversely and inseparably, participants spontaneously introduce a "sonorization of the social" in their comments (ibid.), in particular, by attributing socioacoustic qualities to urban territories. Together these results require moving from an urban ecology framework - while maintaining the idea of differentiation in Park's sense (1952) - to a "sonic ecology" of the city as it is experienced by its residents (Photograph 3 ).

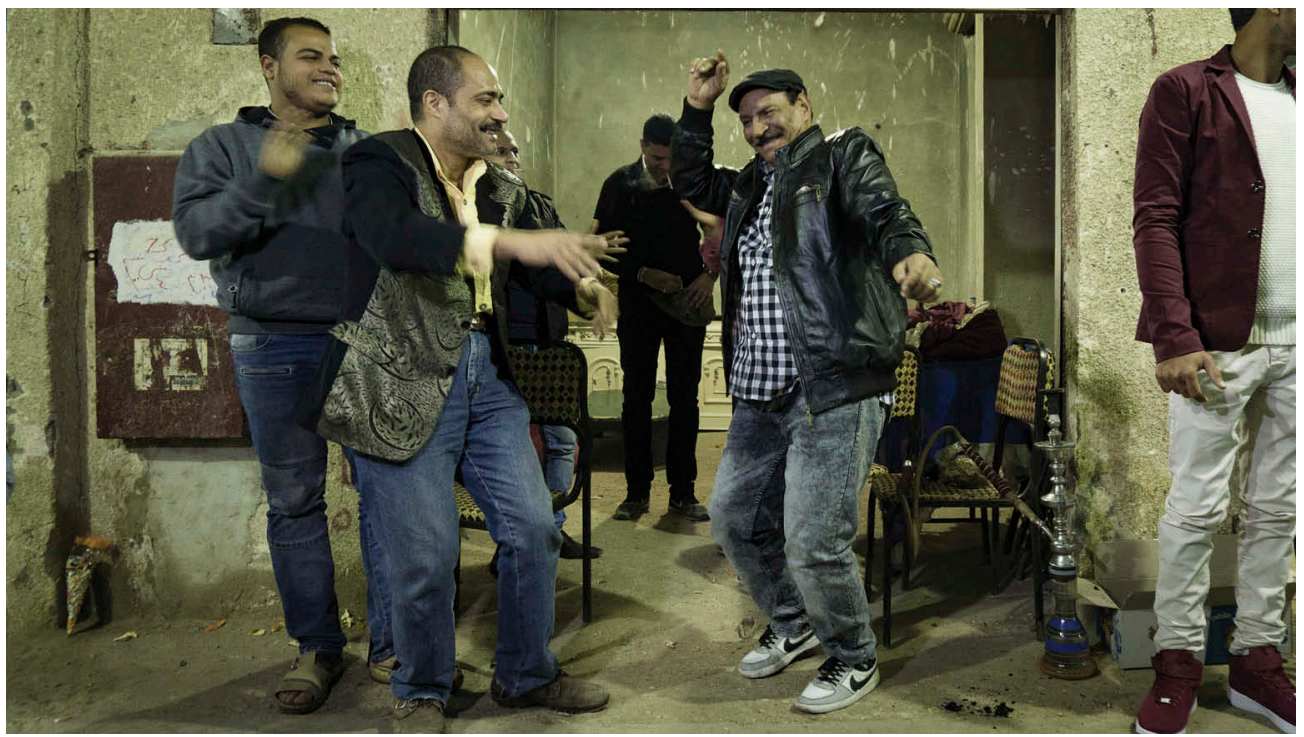

Photograph 3. Detail of a birth party that occupies the entire alley and animates the entire neighborhood in the so-called "informal" district of Bashtil, Cairo, Egypt, early evening, November 18, 2016, by Vincent Battesti. 
Residents' natural attitude allows for a comprehensive listening to the sound environment that is complementary to and often indistinguishable from a listening that we have called "selective listening" [écoute d'abstraction] (Battesti 2013, 77). Competence in comprehensive listening resides in the ability to recognize this sonic whole in its multiple dimensions, in this case of a territory. The sound signatures of territories (which are very hierarchized in Cairo) can be analyzed and broken down (every soundscape can be presented as an inventory of different sounds, whether identified or not, through selective listening). But it is the comprehensive listening, the whole, and not each of the isolated elements composing it, that makes sense here, as conceived in Gestalt psychology (Battesti 2013, 77-78).

Comprehensive listening is particularly evident in the "aural postcards experiment" (Battesti 2017), which enlists a kind of "reactivated listening" (Augoyard 2001). We made sound recordings of ambiances in different neighborhoods and gave these to participants to listen to with headphones. Sometimes participants were able to precisely localize the recording but, most of the time, they focused on the type of neighborhood recorded. In doing so, they inform us of their own categorizations of the sound-city: for example, what a šacabi (popular) neighborhood sounds like, or what the key sound elements of a place are. Their comprehensive listening allows them to identify a set of sounds with a place, but when they have to objectivize their answers, to justify them, the participants highlight certain sounds or sound effects. Listening to a busy evening in downtown Cairo, for example, they note the density of car horns or the hawkers' cries, especially the newspaper vendors ("al-Ahräm, al-Akhbār, alGumhūriyya!" - the three major Egyptian titles) (Battesti 2017). Our "Mics in the Ears" experiment does not really capture this type of listening insofar that it asks participants to describe sounds (selective listening). Nevertheless, some descriptions evoke generic places or toponyms (see above) without specifying what the identification is based on.

These identifications are not free from error. Some participants can become disoriented in spaces they do not know very well (e.g., Shady's walk in Wast al-Balad), and their ability to situate themselves in the city is found wanting. It is true, however, that certain spaces in Wast al-Balad (downtown) offer few saliences to pedestrians, as recounted by Salma, who has trouble distinguishing sounds, finding her reference points, and situating herself among the jumble of sounds:

[11:40] - (...), car horns, the sound of a bus or car, it's the same thing!

Interviewer: You can't tell the difference ... ?

Exactly, that is to say, I will not be able to make the distinction very well, exactly. Us [participants of this procedure], we don't distinguish places [maken], we don't distinguish sites [muwqec], or locations because while walking we receive [ben'äbel] a lot of sounds [așwät], the sounds of cars, many cars, the sounds of many micro[buses], buses, uh ... microbuses, yes, all of that. [Salma]

(b) - The sounds of others

A sense of the great diversity of social worlds is widely shared among Cairo's residents. This is accompanied by different spaces being perceived through the prism of social and cultural criteria. This phenomenon manifests itself in two ways. First of all, a clear apprehension of the divisions in society fosters strong sentiments about what each individual's position should be. The "sense of one's place" applies not only to one's metaphorical 
social position, but also to the urban territory that one assumes the right to enter, partake in, inhabit or invest, in one way or another. This sense of self in the city then shifts to the city of others: spaces are overlaid with social and entirely cultural criteria. The morphology of cities is characterized by a partitioning of the very diverse social and economic worlds that comprise them. These segmentations delineate a plural city in which residents develop highly differentiated practices and "visions" (Battesti and Puig 2011) that extend far beyond the visual. Participants engage in a particularly explicit differentiation between sounds associated with the city's different spaces:

[01:03:00] - (...) The residents of Misr al-Gedīda come to the neighborhood [of Fatimid Cairo] to observe people, stores, trades, they take in the odor of this part of the city. They hear the sounds [aswat] of this part (of the city) [heta], that is to say this part here, it is not possible to walk down a street in Misr al-Gadida and hear this sound. What you are hearing there, it is not possible. Garden City, it is not possible to hear this. Helwan, Helwan you cannot at all. AlMacādī, you cannot hear these sounds [așwat], not at all: only in this neighborhood. [Hassan \#1]

This process of identifying sound differences between Cairo's neighborhoods also takes place during participants' walks as they pass from one space to another. These transitions have a threshold effect that is not noted as such by participants; they mention, rather, changes in ambiances (gaw in Egyptian) between a busy street and an alleyway or a more domestic micro-neighborhood (hara), or between an exterior and interior space. For example, Salma (description 23:20) notes the rupture in ambiance between an avenue in Wast al-Balad and an outdoor café that she is heading toward, which is located in an alleyway (the effect is audible on the recording track of the walk, starting at 23:20). Hassan \#2 (10:05) and Maurice (6:44) similarly identity a threshold crossing when entering a store or bakery. Finally, Samir identifies his return to hara (probably thanks to familiar voices):

[17:10] - Now, it's someone passing next to me on a bike. This too, it's a tūktūk. This, these are kids who have rented bikes at the beginning of the street. This, this is uncle Shaaban, the imam of the mosque near my home who is greeting me. This is it, now l've entered the street.

Interviewer: You've entered the street?

[17:43] - Yes, this is it, now I've entered the hara, so, I've finished. Now, it's a sound of banging [sawt al-taxbit] from behind here, they're building something. This, these are the same voices (sawt) of the children who were talking when I came down at the very beginning, they're below. [Samir]

(c) - The values of the sounds of social life

Finally, the results of our procedure indicate an absence of hierarchization in the way sound experience is depicted by participants: sounds are noted without placing more value on one over the other. There are thus no prominent categorizations, for example, of the religious over the rest of the sound life, but more of an undifferentiated sound continuum in which the sounds of the mosque, of the recitation of the Quran, exist alongside the sounds of the cafe or the voices of children. All of the fields of social life (commercial, religious, behavioral, playful, etc.) are closely interlinked, and participants' ears are sensitive to all of these fields at once. While residents contribute collectively to the production of the sound ambiance, some actively participate in the urban concert. The soundwalks reveal the omnipresence of music 
emanating from vehicles (cars, Vespas) and businesses trying to attract customers with their sound print. They also reveal the very frequent use of Quranic recitations. This is above all a custom of storekeepers opening their shops in the morning. The recitation plays a protective role for the store and facilitates business as it serves as a screen for other sounds, less to mask them than to legitimize them. The following example [Hassan \#1] highlights this interlinked dimension of all of the fields of social life:

[46:54] - This one here, he doesn't need to put music on, he needs the Quran at all times. Workers play the Quran night and day to deter a neighbor coming down and annoying them, saying "enough with your racket, we want to sleep!" So they say, "you don't like this, I'm playing the Quran." Thus begins the row: (...) I'm bothering you with my Quran? or with my hammering?" You use both, one drowns out the other (...) In the trades that make loud noises, play the Quran.

[47:56] - Interviewer: Because it drowns out the noise they're making.

[47:56] - Yes, you can't go to the police station, you go to the station and say to them "this guy's bothering me"? "And what's bothering you?" "The guy's playing the radio, come and see oh representatives of order see what he's got this guy." (The guy will respond:) "I'm a guy who adores our God, I am devoted to God, I'm sharing the Quran." They're going to chop and hit [the plaintiff]. The guy is actually listening to the Quran. "If you follow the Quran, then listen to it." What are you, an infidel? [Hassan \#1]

This dialogue from Hassan's comments reveals the interconnection between the sacred and the profane in everyday life. Indeed, the sacred is instrumentalized here to serve a practice that is profane, professional, and acoustically disruptive, which suggests that listening to the Quranic recitation does not have the sole motive of recalling or connecting with the divine (nor of forming an ethical or political community), and that the diffusion of sounds, even the sacred, is based on various motivations.

One criterion put forward, which one participant relates as much to the economy as to a neighborhood's micro-culture, is the sonority of voices as a social (semiological) index in working-class neighborhoods. Hassan spontaneously proposes a social theory that links socio-economic levels to sound levels:

[16:49] - (...) When the economy is fragile, poor and destitute people, they speak in a loud voice [betkalemu bi-sawt cali], they yell [betsaraxu bi-sawt cali]. That one is calling this one here for him to bring him a sandwich and another says to him "I'm doing well." The economy is a very influential factor. The café is full, because there's no work, people stay in the café. Even women are in the streets. [Hassan \#2]

[17:55] - In Darb al-Ahmar no, it's not like this, it is something else altogether. The atmosphere [al-manax] is different. The more the economy develops, the more voices are calm, the more people are rich. The more ... the more he is poor, the more he shouts, the louder his voice is. He wants to exist, he's making his presence felt, I exist. [Hassan \#2]

These different soundmarks are combined in Mohammed's description:

[03:13] - (...) And all this, this was children around me walking and talking [atfâl hawaliyya betetkalem wa māšiyya]. And this, this was a cart [hantūrr] and Vespas passing by. And this, the sound [sawt] of a donkey [hemar]! A Vespa is passing. A Vespa again. It's the people [in the street] as if it was exactly in the street where I was walking. This, this was children playing in the distance [atfäl betelcab bacīd]. The sound [șawt] of children playing continues [al- 
sawt māzäl mustamer]. This, it's people who were sitting next to me [عalä gemb], who are bickering [bišeddū macbaḍ fi-l-kaläm], children running [atfäl bitigri] next to me [men gembī]. Again, children running next to me. Thus, this was a fashion boutique [mahal aziyā], the sound [sawt] came from the sound [șawt] very loud [عālī giddān] of the television. This, it's

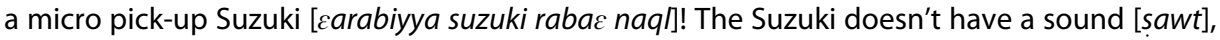
of course... All this, this was the market [sūq], it is still a very popular neighborhood [mantega šacabiyya gidān], people are all out in the streets. [Mohammed]

We note in this example, when comparing it to the audio recordings of his walk, a selectivity in listening that is attentive to faint sounds in the background: he mentions "the very loud sound of the television" (that the authors are not able to isolate), but not the discotheque-level amplified music of the Suzuki, nor the religious sounds that are nonetheless very present. The attention to or perhaps search for audible cues is not always focused on sound events in the foreground, but explores, rather, different depths of the sound space. While Hassan, for example, does not mention people whistling in the street, or the sounds of the mosque, which are very loud at this time, he observes:

[17:40] - Yes it's in the shop, but I wasn't smoking anything, this is the sound [sawt] of motorbikes ... [Hassan \#1]

The notion of foreground/background is perhaps not applicable to this auditory dimension, because listening is a lot more immersive than the visual domain. Spatialization, however, remains pertinent: the expressions "around," "next to," "to the right," and "further away" are used by participants to describe and situate the sounds they hear.

To describe their localization, residents make use of both "indices" - referring to a cause, an event, or an agent - and/or "signs" - referring to a message perceived according to a code, a frame of reference (Battesti 2013,93). These indices are constituted by specific or particular sounds from which a broader social situation can be inferred: for example, the tinkling of the spoon in the cup of tea evokes the café establishment (Mona), just as amplified music in the street evokes the wedding ceremony - farah - (Mona, Hassan \#2, Samir), in accord with the rhetorical figure of synecdoche. ${ }^{5}$

(d) - Urbanities and Sound Environments

In participants' comments, we observe two different positions vis-à-vis sound environments of the working-class type, related to two conceptions of living in the city (urbanities). The first position consists in deploring the intrusion of others' sounds into one's personal auditory sphere (speaking loudly on a cell phone, noisily arguing in the street, etc.). In our sample of participants, this position was evident among residents of relatively well-off neighborhoods (Garden-City and Wast al-Balad). The second position, the opposite model, emphasizes the necessary reciprocal tolerance of each other's sounds, even an emotional attachment to this reassuring "sound coating" typical of working-class urbanity.

Many street conversations - the "city's conversation" - seem at times to take place without any concern for privacy. This was noted very often by participants. These sociabilities are revealing of an encroachment of private affairs into a public or semipublic domain redefined by these specific uses (Battesti and Puig 2011), of a density of bodies (co-presence, voice, footsteps, etc.) in a "society of proximity" (Puig 2003) in which 
social norms, urban culture, and lived territory are closely linked. Due to the restricted space, discomfort, and precarity of dwellings, along with their overpopulation, the domestic sphere spills out into liminal spaces whose status shifts between private life and public openness (Depaule and Arnaud 1985, 90). But this overflow of the domestic sphere and its corollary, a certain publicization of private life, is not only associated with constraint but also gives rise to the development of specific sociabilities that are played out on a stage that is nearly devoid of any "back-stage," following an observation of Wikan (1980, 24-25), even to a certain "aesthetics" of public life. This characteristic of workingclass Cairo not only applies to older neighborhoods, but also to all of the so-called informal settlements that make up the majority, since they house more than half of the Egyptian population alone (Séjourné 2011).

The first position regarding sound environments of the working-class type, as mentioned above, is not one of tolerance or of being immersed, but rather of self-preservation. One of our participants even evoked the idea of "moving aside" in response to the sound of others (see his commentary in Battesti and Puig 2016,314) or of a selective hearing thanks to an auditory "filter in the head." The following example suggests a form of habituation to what the participant still considers to be an invasion of his private sound sphere:

"I'll tell you, for me the doormen there, they live ... . just below in the building's courtyard, I don't hear anymore, I don't hear the noise there anymore, you block it mentally (...)." Maurice

This habituation is shared by residents of working-class neighborhoods (Photograph 4). Faced with the objective density of sounds of their urban life, participants normalize this intensity by frequently repeating "it's common," "it's normal," etc. (Hassan, Leyla, Salma). Listening with the participants to their own recording highlighted differences in appreciation: the authors, though familiar with the city of Cairo, were a lot more surprised by the sound intensity.

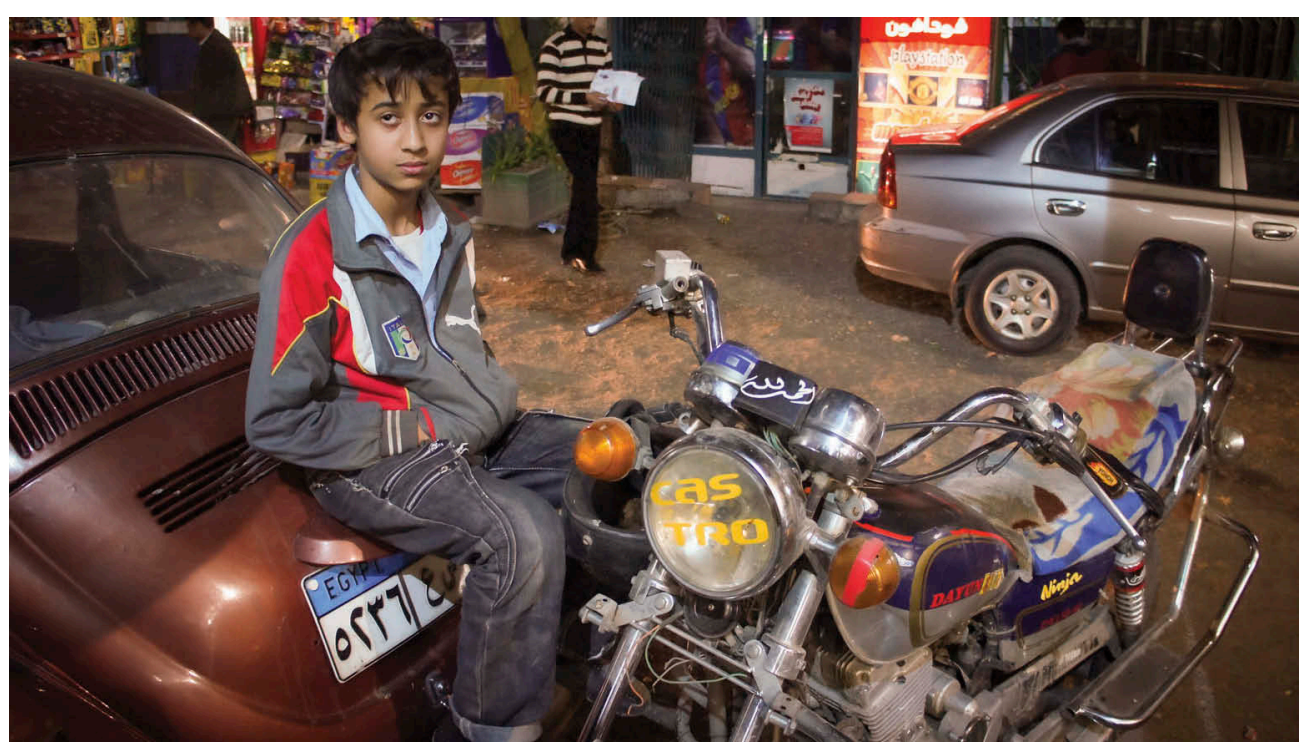

Photograph 4. In al-Helmiya, Cairo's historic popular district; the narrowness of most of its alleys does not allow cars to circulate, Cairo, Egypt, on the night of March 31, 2011 by Vincent Battesti. 


\section{Conclusion}

The purpose of the "Mics in the Ears" experiment was to get as close as possible to the sound perceptions of Cairo's residents in order to shed light on what constitutes a sensory experience of the city. To achieve this goal, we devised a new ethnographic tool as part of the sonic methodologies (Battesti forthcoming 2020) baptized "Mics in the Ears," which we describe in a previous article published in this same journal (Battesti and Puig 2016). The results obtained are particularly rich, and part of the material remains open to exploration, which is why we are submitting the whole set of audio and written data as supplementary material.

What conclusions can we draw from all of this? In the first instance, participants' descriptions of and comments on their soundwalks allowed us to establish a lexicon comprising more than 600 entries that we classified according to our own criteria (others are possible). We identified a "natural language of sounds" organized around nouns, sources, qualificatives/descriptives, actions/verbs, and localization. The data thus obtained revealed covert (implicit) categories that describe three key domains of urban life: the active city, the city in movement, and the relational city. A principal finding is that sound perception systematically relates sounds to their origin, which includes both the source and its social situation. This socialization of sound led us to propose the notion of "sound constructs" as products of an immediate socialization of the perception of sound (as distinct from Pierre Schaeffer's "sound object"). The results of our study also contradict the assumption of a "direct perception" of the environment (Ingold 2000, 2018; see further Howes 2019). The procedure and its results constitute the basis for a reflection on how perception operates in Cairo, which involves a differentiation between territories (based on sound saliences and soundmarks).

As a final step, we sought to develop a "sonic ecology" of the city that would help us understand how residents collectively experience the sound dimensions of their urban territory, navigate between very different territories of the city, and recognize and respond to them. This is shown to call upon analytic and semantic competencies, without important cultural differences (apart from appreciation) playing a role, the grain of our study being particularly fine. Nonetheless, this type of study could be applied to other national and international urban contexts and provide heuristic comparisons. While Kevin Lynch has proposed an analysis of the visual perception of urban landscapes (The Image of the City, 1960), their auditory dimension remains to be subjected to the same rigorous ethnographic study. Beyond its contribution to knowledge on perception and the data collected, we hope this research will renew interest in urbanity by taking into consideration the sonic, and more broadly, sensorial dimension of cities in their connection to social dynamics.

\section{Notes}

1. For a short definition: emic is from within the social group (from the perspective of the subject) and etic is from outside (from the perspective of the observer) - (On these notions, see Olivier de Sardan 1998).

2. Our definition differs somewhat from that of R. Murray Schafer, who derives the term soundmark from the term landmark "to refer to a community sound which is unique or possesses qualities which make it specially regarded or noticed by the people in that community" (Schafer 1977 [1994], 274). 
3. See also Puig (2017) on the recent changes of the sound environment in Cairo in relation to sound technologies.

4. According to Renaud Barbaras, "our perceptual activity is inseparable from movement" (2009, 92).

5. Synecdoche is also inversely employed to refer to a whole to signify a part: the mosque for the sound of the call to prayer, for example.

\section{Acknowledgments}

The authors would like to thank the two anonymous reviewers, appointed by the journal, for their enthusiasm and, once again, Carmen Ruschiensky for her highly professional translation of this study.

\section{Disclosure statement}

No potential conflict of interest was reported by the authors.

\section{Notes on contributors}

Vincent Battesti is a researcher in social anthropology at the CNRS (French National Scientific Research Center), his office is at the Musée de l'Homme (National Museum of Natural History) in Paris: lab. Éco-anthropology, where he co-leads the Ethnoecology research team. He is also associate editor of the journal Revue d'ethnoécologie. His ethnographic fieldworks are mainly located in North Africa and the Middle East, in particular in Tunisia, Egypt, Yemen, and Saudi Arabia. He questions the different forms of relationship to the environment of social groups, through their knowledge and practices of the living and spaces or through their means of knowledge and practices (the sensory), in oases or in urban areas. Website: https://vbat.org

Nicolas Puig is a researcher in social anthropology at the Unité de recherche migrations et sociétés (IRD, CNRS, Paris University and Nice University). His research is situated at the crossroads of urban anthropology and the anthropology of music and sound. After working on social and urban change in the city of Tozeur in southern Tunisia, he is now pursuing field research in Cairo and in Palestinian camps in Lebanon. In these different contexts, he investigates social, cultural and political dynamics through the prism of musical practices and the making of sound environments. Website: https://cv. archives-ouvertes.fr/nicolas-puig

\section{ORCID}

Vincent Battesti (D) http://orcid.org/0000-0002-5793-1098

Nicolas Puig (D) http://orcid.org/0000-0003-4828-9395

\section{References}

Amin, Galal A. 2000. Whatever Happened to the Egyptians? Changes in Egyptian Society from 1950 to the Present. Cairo: American University in Cairo Press.

Augoyard, Jean-François. 2001. "Entretien sur écoute réactivée." In L'espace urbain en méthodes, edited by Michèle Grosjean and Jean-Paul Thibaud, 127-152. Marseille: Éditions Parenthèses.

Augoyard, Jean-François. 2003. “Une sociabilité à entendre." Espaces et sociétés 115 (4): 25-42. doi:10.3917/esp.g2003.115.0015.

Barbaras, Renaud. 2009. La perception, Essai sur le sensible, Moments philosophiques. Paris: J. Vrin. 
Battesti, Vincent, and Nicolas Puig. 2011. "Comment peut-on être urbain? Villes et vies urbaines." In L'Égypte au présent, Inventaire d'une société avant révolution, edited by Vincent Battesti and François Ireton, 145-182. Paris: Sindbad-Actes Sud.

Battesti, Vincent. 2013. "'L'ambiance est bonne' ou l'évanescent rapport aux paysages sonores au Caire. Invitation à une écoute participante et proposition d'une grille d'analyse." In Paysages sensoriels. Essai d'anthropologie de la construction et de la perception de l'environnement sonore, edited by Joël Candau and Marie-Barbara Le Gonidec, 70-95. Paris: éditions du CTHS.

Battesti, Vincent. 2017. "Mics in the Ears: How to Ask People in Cairo to Talk about Their Sound Universes." In Toward an Anthropology of Ambient Sound, edited by Christine Guillebaud, 134-152. New York: Routledge.

Battesti, Vincent. forthcoming 2020. "Ethnographies Sounded on What? Methodologies, Sounds, and Experiences in Cairo." In Handbook of Sonic Methodologies, edited by Michael Bull and Marcel Cobussen, 1-28. London: Bloomsbury Press.

Battesti, Vincent, and Nicolas Puig. 2016. "'The Sound of Society': A Method for Investigating Sound Perception in Cairo." The Senses \& Society 11 (3): 298-319. doi:10.1080/ 17458927.2016.1195112.

Berlin, Brent, Dennis E. Breedlove, and Peter H. Raven. 1968. "Covert Categories and Folk Taxonomies." American Anthropologist 70 (2): 290-299. doi:10.1525/aa.1968.70.2.02a00050.

Candau, Joël, and Olivier Wathelet. 2011. "Les catégories d'odeurs en sont-elles vraiment ?" Langages 181 (1): 37-52. doi:10.3917/lang.181.0037.

Chion, Michel. 1983. Guide des objets sonores, Pierre Schaeffer et la recherche musicale, Bibliothèque de recherche musicale. Paris: Buchet/Chastel: Institut national de la communication audiovisuelle.

Depaule, Jean-Charles, and Jean-Luc coll. Arnaud. 1985. À travers le mur. Vol. 9. Alors. Paris: Centre de création industrielle, Centre Georges Pompidou.

Féraud, Olivier. 2010. "Voix publiques. Environnements sonores, représentations et usages d'habitation dans un quartier populaire de Naples." doctorat d'Anthropologie sociale et ethnologie, École des hautes études en sciences sociales (EHESS).

Hannerz, Ulf. 1980. Exploring the City: Inquiries toward an Urban Anthropology. New York: Columbia University Press.

Howes, David. 2019. "Multisensory Anthropology." Annual Review of Anthropology 48 (1): 17-28. doi:10.1146/annurev-anthro-102218-011324.

Ingold, Tim. 2000. The Perception of the Environment: Essays on Livelihood, Dwelling \& Skill. London: Routledge.

Ingold, Tim. 2018. "Back to the Future with the Theory of Affordances." HAU 8 (1/2): 39-44. doi:10.1086/698358.

Krause, Bernard L. 2002. Wild Soundscapes: Discovering the Voice of the Natural World: A Book and CD Recording. 1st ed., Wilderness Press Series. Berkeley: Wilderness Press.

Krause, Bernie. 2012. The Great Animal Orchestra: Finding the Origins of Music in the World's Wild Places. London: Profile Books.

Lynch, Kevin. 1960. The Image of the City. Cambridge, MA: Massachusetts Institute of Technology Press.

Olivier de Sardan, Jean-Pierre. 1998. “Émique." L'Homme 38 (147, Alliance, rites et mythes): 151-166. doi:10.3406/hom.1998.370510.

Park, Robert Ezra. 1952. Human Communities: The City and Human Ecology, His Collected Papers. Glencoe, IL: Free Press.

Puig, Nicolas. 2003. "Habiter à Dûwîqa au Caire, Dedans et dehors d'une société de proximité." Autrepart 25 (1): 137-152. doi:10.3917/autr.025.0137.

Puig, Nicolas. 2005. "Variétés urbaines, Perceptions des lieux et positionnements culturels dans la société cairote à travers quelques chansons populaires." In Les manifestations de l'urbain dans le monde arabe, edited by Jean-Luc Arnaud, 195-220. Tunis, Paris: IRMC, Maisonneuve et Larose.

Puig, Nicolas. 2017. "La ville amplifiée, Synthétiseurs, sonorisation et effets électro-acoustiques dans les rituels urbains au Caire." Techniques \& Culture Suppléments au n ${ }^{\circ} 67$. http://tc.revues.org/8504

Rosch, Eleanor H. 1973. “Natural Categories." Cognitive Psychology 4 (3): 328-350. doi:10.1016/00100285(73)90017-0. 
Schaeffer, Pierre. 1966. Traité des objets musicaux, essai interdisciplines, Pierres vives. Paris: Éditions du Seuil.

Schafer, R. Murray. 1977 [1994]. The Soundscape: Our Sonic Environment and the Tuning of the World. Rochester, VT: Destiny Books.

Schafer, R. Murray; World Soundscape Project. 1978. The Vancouver Soundscape, Music of the Environment Series. Burnaby, BC: World Soundscape Project, Sonic Research Studio, Dept. of Communication, Simon Fraser University.

Schütz, Alfred. 1962. Collected Papers I: The Problem of Social Reality, Phaenomenologica. The Hague: Martinus Nijhoff Publishers.

Séjourné, Marion. 2011. "La "banalité" d'une urbanisation illégale." In L'Égypte au présent, Inventaire d'une société avant révolution, edited by Vincent Battesti and François Ireton, 111-128. Paris: Sindbad-Actes Sud.

Wikan, Unni. 1980. Life among the Poor in Cairo. Translated by Ann Henning. London, NY: Tavistock Publications. 